\title{
A Correlation Analysis of Factor Causing Occupational Accident with the Unsafe Behavior of Welding Workers of Division of Commercial Ships, PT. PAL Indonesia (Persero) Surabaya
}

\author{
Lupita Noviyanti, Abdul Rohim Tualeka2, Yustinus Deni Ardianto2 \\ IStudent in Magister of Occupational Health and Safety, ${ }_{2}$ Lecturer in Departement of Occupational Health and \\ Safety, Faculty of Public Health, Airlangga University, Campus C Mulyorejo, Surabaya-Indonesia
}

\begin{abstract}
Welding activities in the shipbuilding industry PT. PAL INDONESIA (Persero) Division of Commercial Ships, containing a high hazard risk. Hazard that is not analyzed could lead to accidents. Cases of occupational accidents can result in losses. This is because there are many workers who work without PPE and not paying attention to the SOP. The general objective of this study was to analyze the factors that cause accidents on welding workers of PT. PAL INDONESIA (Persero) Division of Commercial Ships by using the approach of ILCI, Loss causation model seen from the lack of management control (lack of control), the basic causes (basic causes) and the immediate cause (immediate cause) occupational accidents are unsafe behavior (unsafe act).

This study was an observational study with cross sectional approach that was conducted in February-March 2017 to 72 out of 87 welding workers on a commercial ship division. Selection of respondents were taken by simple random sampling method. The data obtained were collected from questionnaires, interviews and observation. Data were analyzed descriptively and described in narrative form and cross tabulation.

Result obtained based on the fisher exact correlation analysis demonstrated that there is a correlation between the policy of $\mathrm{K} 3$, the training of $\mathrm{K} 3$ and $\mathrm{SOP}$ with the individual commitment. Individual commitments linked to unsafe behavior.
\end{abstract}

Keywords: Accidents, unsafe behavior, welding workers

\section{INTRODUCTION}

Implementation of safety in every workplace as mandated by Law No. 1 of 1970 and Law No. 13 of 2003 on employment, the duty of employers to protect workers from potential hazards faced. All to create working conditions that are safe, healthy, free of accidents conditions and occupational diseases 1 .

In general, the direct cause of the (immediate cause) occupational accidents are unsafe behavior (unsafe act) and unsafe working conditions (unsafe conditions). Based on several studies described that many workplace accidents occur due to unsafe behavior. This is supported by the results of research on the NCS (National Safety
Council) on the causes of accidents. NCS research results indicate that the causes of accidents $88 \%$ is their unsafe behavior, $10 \%$ due to the unsafe condition and $2 \%$ did not know the cause. Another study conducted by DuPont Company showed that $95 \%$ of workplace accidents are caused by unsafe behavior and $4 \%$ are caused by unsafe action.Penyebab directly preceded by the basic causes (basic cause). The basic cause must be identified as highly effective in preventing the occurrence of kerugian2.

The basic cause may help explain why the loss. The basic cause may help explain why the unsafe act and unsafe condition3.Penyebab basis accidents are categorized into two, namely the occupational factors 
and personal factors. Personal factors consist of lack of knowledge, skill, motivation, setress and inability to cope with stress, while the employment factor consists of the leadership, equipment and tools tidaksesuai, ergonomics and design of work stations as well as errors in using peralatan 4.

A series of events and processes that lead to accidents and loss of control or monitoring indicates that less controllable management (lack of control). The theory of loss causation model of the Bird and Germain modifying Domino Theory Heinrich to put forward the theory of management that is less controllable (lack of control), the basic causes (basic cause), the immediate cause (immediate cause), contacts and accident (incident) and loss (loss )5.

Based on research by the world body of the International Labor Organization (ILO) (1989) concludes that every day an average of 6,000 people died, this is equivalent to one person every 15 minutes, or 2.2 million people per year due to sickness or an accident that relate to their work. According to the ILO in 2013 estimated 337 million occupational accidents each year and 2.3 million work-related deaths occurred. The number of men who died two times more than women, because they are more likely to do dangerous work. Overall, accidents in the workplace has killed 350,000 people6.

According to the Social Security Agency (BPJS) registering employment throughout the year 2013 the number of participants who had an accident as much as 129911 people, and of these $75.8 \%$ were male. The number of such accidents mostly occur or approximately $65.59 \%$ in the company when they work, while outside the company as much as $10.26 \%$ and the rest, or about $20.15 \%$ were traffic accidents suffered by workers. A total of 32, $12 \%$ of workers not wearing safety equipment. Furthermore, $51.3 \%$ of causes of accidents due to collision, while the body most exposed to injury is the finger then the foot. Most injury causation of $32.25 \%$ was machinery. Number of accident insurance claims to be paid to the participants during 2013 reached 618.49 billion rupiah7.

According to research conducted by Sulfikar (2015) explains that the cases of occupational accidents in unloading dock workers during the past two years emeralds are still quite high. The number of cases of occupational accidents occurred 62 times, resulting in two people died, 18 people were seriously injured, and 42 people were slightly injured. Workplace accidents every year will result in many losses for both the company and the tenant services workers unloading. In this Jamrud Pier in 2013 never happened a fatality incident which left one person killed by falls from height during the process of loading and unloading caused by Unsafe Action8.

Based on work accident reporting data obtained from the management of K3 PT. PAL INDONESIA (Persero) Surabaya, Division of Commercial Ships, known cases of accidents to personnel during the last 2 years (2014-2015) is still quite high. The number of accidents occurred in 2014, as many as eight cases with severe injury category. Then in 2015 the increase in the incidence of accidents with 19 cases of accidents and serious injuries which resulted in $90 \%$ due to unsafe action. Therefore, this study aimed to analyze the relationship between causes of accidents with unsafe behavior on welding worker PT. PAL INDONESIA (Persero) Surabaya, Division of Commercial Ships using Ilci then analyzed by Fisher exact test.

\section{MATERIAL AND METHOD}

\section{Participant}

This research be an observational study with cross sectional design and implemented during the first month ie March to April 2017, located in PT. PAL INDONESIA (Persero) Surabaya, Division of Commercial Ships.

The population in this study were all workers welding PT. PAL INDONESIA (Persero) Surabaya, Division of Commercial Ships. Sampling in this study using simple random sampling technique, totaling 72 workers welding. The data collection technique using questionnaire and observation checklist sheet.

\section{Procedures}

The first step to doing this study is to pengumpulam primary data obtained by asking permission to the company management, then followed by asking respondents willingness welding selected as the sample for the respondent. A questionnaire/ assessment questionnaires workers against the company policy $\mathrm{K} 3$, $\mathrm{K} 3$ and SOP training, individual commitment, and unsafe behavior, then given to the respondent to be completed. After filling out the questionnaire followed by observation in the workplace with the aim to find 
out firsthand how the work process and work behavior among respondents of welding workers.

\section{DATA ANALYSIS}

In this study, to analyze the relationship between the causes of accidents with unsafe behavior on welding worker PT. PAL INDONESIA (Persero) Surabaya, Division of Commercial Ships by using fisher exact test. Factors causes of accidents with unsafe behavior on welding worker is influenced by many factors including the policies of $\mathrm{K} 3$, the training of $\mathrm{K} 3$, SOP, individual commitment, do not comply with the SOP of welding.

\section{FINDINGS}

1. The correlation of K3 policy with Individual Commitment

Of the 72 worker's it is known to the majority of workers welding has less votes on policy $\mathrm{K} 3$ in the workplace. This is explained by the percentage value of $92.3 \%$, which means that according to the policy if the workers vote $\mathrm{K} 3$ is less then the commitment of individual workers are also less, it is shown by the percentage value of $55.0 \%$. Fisher's Exact test results obtained by value $\mathrm{p}$ value of 0.001 . It shows a significant relationship between policy $\mathrm{K} 3$ with individual commitment.

$\mathrm{K} 3$ policy is an important requirement in the implementation of $\mathrm{K} 3$ management system in the organization. $\mathrm{K} 3$ policy is a clear form of management commitment to $\mathrm{K} 3$ are set forth in a written statement. Rate respondents about K3 good policy does not increase individual commitment. This can happen because the $\mathrm{K} 3$ in the company policy is a form of management's commitment to the implementation of $\mathrm{K} 3$ in the company. K3 policy is not a form of worker commitment to organisation9.

$\mathrm{K} 3$ related management commitment must be shown obviously in activities and everyday attitudes contained in each policy organization. Management must support the success of $\mathrm{K} 3$ by showing commitment can be seen (visible commitment) and felt by all elements of the organization. Commitment is crucial as a reference and guide for all parties in implementing $\mathrm{K} 3$ in the organization. Therefore, companies should immediately conduct socialization of written policy10.

2. The correlation of $\mathrm{K} 3$ training with Individual Commitment
Of the 72 worker's it is known to the majority of workers welding has less of $\mathrm{K} 3$ training assessment in the workplace. This is explained by the percentage value of $90.3 \%$, which means that according to the judgment $\mathrm{K} 3$ training workers in the company is less, but the commitment of individual workers is good, it is indicated by the percentage value of $70.0 \%$. The results obtained by Fisher's Exact test obtained p-value of 0.000 . It shows a significant relationship between the training of $\mathrm{K} 3$ with the individual commitment.

Individual commitments may develop as the organization provide something of value that can not be replied back. Moreover, since there are psychological contract (the trust of all parties that there would be reciprocal) between members of the organization. Training K3 is something valuable that can be given by the organization to its employees and cannot be replied back by the workers11.

Therefore, companies need to implement periodic K3 training and labor-encompassing old and new, it is intended to update the knowledge and understanding of the implementation of the program on the issues - the latest $\mathrm{K} 3$ issue that is being experienced by the company.

3. The correlation of SOP with Individual Commitment

Of the 72 worker's it is known to the majority of workers welding has less votes of SOP in the workplace. This is explained by the percentage value of $90.5 \%$, which means that in the opinion of workers in the company SOP less, but the commitment of individual workers is good, it is indicated by the percentage value of $77.8 \%$. The results obtained by Fisher's Exact test p-value of 0.000 . It shows a significant relationship between the SOP with individual commitment.

By performing the application of SOP organization can ensure an operation run in accordance with the existing procedures and if SOP implemented correctly, then the organization will gain many benefits from the implementation of the SOP. SOP plays an important role in meeting labor standards that exist in the organization. The better the performance of workers, hence further reducing the risk of unsafe behavior that can create the scene of the accident and unsafe working conditions 12 .

Therefore, in the company SOPs should be reviewed periodically and communicated to each unit of work, 
because there are many workers who have not quite understand the function and usability of the SOP that has been made by the company.

4. Individual commitment

Of the 72 worker's it is known to the majority of workers welding has less votes on the commitment of individuals in the workplace. This is indicated by the percentage value of $83.1 \%$, which means that according to the judgment of individual commitments workers working less, but the behavior of workers is safe, it is indicated by the percentage value of $76.9 \%$. The results obtained by Fisher's Exact test p-value of 0.000 . Hasilinimenunjukkan a significant relationship between individual commitment to unsafe behavior of workers.

Individuals who have a passive individual commitments will allow only state that did not go well. Workers who have committed individual with such circumstances, we can just leave the unsafe behavior, either by himself or done by others around them. This shows that the majority of its respondents had a passive individual commitments that would tend to leave the safety behavior13.

\section{CONCLUSION}

1. There is a correlation between lack of control (policy, training K3, SOP) with individual commitment. The better the workers vote on policy K3, K3 training and SOP indicate they will also have good individual commitments.

2. There is a relationship between basic factor causes (individual commitments) with the unsafe behavior. The better the assessment of workers on individual commitment, then indicate workers to behave safely.

\section{Conflict of Interest: None}

Source of Funding: Department Of Occupational Health and Safety, Airlangga University, Surabaya, Indonesia.

Ethical Clearance : The study was approved by the institutional Ethical Board of the Public Health, Airlangga University.

All subjects were fully informed about the procedures and objectives of this study and each subject prior to the study signed an informed consent form.

\section{REFERENCES}

1. Tarwaka, (2012). Base- Basic Safety And Prevention of Accidents in the Workplace. Surakarta: Hope Press.

2. Karyani, (2005). Factors - factors that affect the safe behavior (safe behavior) in Indonesia in Schlumber 2005. thesis. FKM UI Depok.

3. Ayuni, AP, (2016), Relationship Analysis Causes of Accidents With Work Behavior Surgical Hospital Surabaya, thesis. FKM Airlangga University Surabaya.

4. Tarwaka, (2015). Occupational Health, Safety and Ergonomics (K3E) In a business perspective. Surakarta: Hope Press.

5. Bird, FE and GL (1990). Practical Loss Control Leadership. Revised Edition. USA: Division OF International Loss Control Institute.

6. ILO, (1998). Encyclopedia Of Occupational Health and Safety. Volume 1 - 4. 4th edition. Stellman, Jeanne Mager (ed). Geneva. Switzerland.

7. BPJS, (2013). Work accident. Available Fromhttp:// www.bpjsketenagakerjaan.go.id/berita/2943/ AngkaKasus-Kecelakaan-Kerja-2013.html

(Accessed December 24, 2016).

8. Sulfikar, (2015). Analysis Factors Associated With Behavioral Safety (Safety Behavior) (Studies in Jamrud Pier TKBM Tanjung Perak Year 2015), thesis. FKM UNIVERSITY SURABAYA.

9. Ramli, S, (2010). Smart Safety, SMK3 Effective Implementation Guide. Jakarta: PT. Dian Rakyat.

10. Notoadmojo S, (2010). Health Research Methodology. Jakarta: PT. Rineka Reserved.

11. Allen, NJ, and JP Mayer.1990. The Measure and antecedents of Affective, Continuence, and Normative Commitment to the Organization. Journal of Occupational Psychology. Vol. 63, No. 17 Agutus 2011.. 1-18.

12. Zamrotun, (2012). Overview of Factors Gen Trans Jakarta Bus Accident Corridor III (KalideresHarmoni) 2012. thesis. UIN FKIK Syarifhidayatullah.

13. Geller, E.Scott, (2001). The Pshychology Of Safety Handbook. USA: Lewis Pubhliser.

11. Helmreich, R. L., \& Merritt, A. C., (2001). Culture at work in aviation and medicine: National, 
Porganizational, and professional influences (2nd

ed.). Hampshire, UK: Ashgate Pub Ltd.

12. Ajzen, Icek., (2015). Consumer Attitudes And Behavior: TheTheory Of Planned Behavior Applied To FoodConsumption Decisions. Rivista di Economia Agraria, Anno LXX, no. 2, 2015: 121-138

13. Ba'agil, Cicik Sechah Hasan., (2012). The Influence of Midwife Awareness Situation to Intention in Service of IUD and Implant Contraception with Behavior Beliefs, Normative Beliefs and Control Beliefs as Determinant, dissertation. Faculty of Public Health. University Of Airlangga Surabaya.

14. Denan, Zarina., Othman, Akmal Aini., Ishak, Muhammad Noor Izami., Kamal, Mohd Fazril Mustaza., Hasan, Muhammad Hanif., (2015). The Theory of Planned Behavior and Self-Identity Factors Drive Graduates to Be Indebtedness. International Journal of Social Science and Humanity, Vol. 5, No. 4

15. Ajzen, Icek., (2005). Attitudes, Personality and Behavior. New York : Open University Press

16. Ajzen, Icek., (1991). The Theory of Planned Behavior. Organizational Behavior And Human Decision Processes 50, 179-2 